\title{
HUBUNGAN OBESITAS DENGAN KEJADIAN PREEKLAMPSIA PADA IBU HAMIL
}

\author{
Ni Luh Putu Dewi Purnamasari Ziarno ${ }^{1^{*}}$, Ivana ${ }^{1}$, A.Fahira Nur ${ }^{2}$ \\ ${ }^{1}$ Mahasiswa Kebidanan STIKES Widya Nusantara Palu \\ ${ }^{2}$ Bagian Kebidanan STIKES Widya Nusantara Palu \\ `E-mail : nilluhputudewi@gmail.com
}

Masalah kesehatan adalah suatu masalah yang sangat kompleks yang saling berkaitan dengan masalah-masalah lain di luar kesehatan sendiri. Banyak faktor yang mempengaruhi kesehatan, baik kesehatan individu maupun kesehatan masyarakat. Faktor yang mempengaruhi derajat kesehatan adalah lingkungan, perilaku, pelayanan kesehatan, dan herediter. Keempat faktor tersebut disamping berpengaruh langsung kepada kesehatan, juga saling berpengaruh satu sama lainnya. Status kesehatan akan tercapai secara optimal, bilamana keempat faktor tersebut secara bersama-sama mempunyai kondisi yang optimal. [1]

Kematian ibu dibagi menjadi kematian langsung dan tidak langsung. Kematian ibu langsung adalah sebagai akibat komplikasi kehamilan, persalinan atau masa nifas dan segala intervensi atau penanganan tidak tepat dari komplikasi tersebut. Kematian ibu tidak langsung merupakan akibat dari penyakit yang sudah ada dan atau penyakit yang timbul sewaktu kehamilan yang berpengaruh terhadap kehamilan. [1]

\section{PEMBAHASAN}

Berikut ini merupakan hasil pembahasan yang akan penulis bahas sebagai berikut:

Obesitas diartikan sebagai suatu keadaan dimana terjadi penimbunan lemak yang berlebihan di jaringan lemak tubuh dan dapat mengakibatkan terjadinya beberapa penyakit. [1]

Obesitas adalah salah satu faktor yang paling umum menyebabkan umur harapan hidup (UHH) lebih pendek dan beberapa penyakit. [1] 
Hubungan obesitas dan hipertensi dalam kehamilan terlah diketahui sejak lama dan kedua keaadaan ini sering dikaitkan dengan peningkatan resiko penyakit kardio vaskuler. Strategi untuk mencegah kenaikan berat badan dan obesitas telah terbukti menjadi lebih mudah dan murah daripada terapi yang ditujukan jika orang telah menjadi gemuk. [1]

Sedangkan pengertian preeklamsia merupakan salah satu penyebab kematian ibu hamil, dengan predisosisi yaitu kehamilan ganda, diabetes melitus, riwayat hipertensi ibu, obesitas, molahidatidosa, sosial ekonomi rendah, paritas ibu dan primigravida muda umur $<20$ tahun dan primigravida tua umur $>35$ tahun. [1]

Preeklampsia ialah sindroma spesifik kehamilan berupa berkurangnya perfusi organ akibat vasospasme dan aktivasi endotel. Penyakit ini umumnya terjadi dalam triwulan ke-3 kehamilan, tetapi dapat terjadi sebelumnya. Untuk menegakkan diagnosis preeklamsia, kenaikan tekanan sistolik harus $30 \mathrm{mmHg}$ atau tekanan sistolik diatas atau sama dengan $140 \mathrm{mmHg}$ atau lebih. Atau apabila kenaikan tekanan darah diastolik naik $15 \mathrm{mmHg}$ atau lebih, atau tekanan diastolik diatas atau sama dengan $90 \mathrm{mmHg}$ atau lebih serta adanya proteinuria. [2]

Preeklamsia menurut tinggal keparahannya dibagi menjadi dua yaitu:

1) Preeklamsia ringan, preeklamsia ringan dapat ditegakan bila ditemukan hipertensi dengan tekanan darah lebih 140/90 $\mathrm{mmHg}$, proteinuria lebih dari sama dengan $300 \mathrm{mg} / 24$ jam atau $>+1$ dipstik serta perdapat odema tetapi odema lokal tidak dimasukan kedalam kriteria kecuali odema lengan, muka dan perut, odema generalisata. [2]

2) Preeklamsia berat, preeklamsia dengan tekanan darah sistolik lebih dari sama dengan $160 \mathrm{mmHg}$ dan tekanan darah diastolik lebih dari atau sama dengan $110 \mathrm{mmHg}$ disertai proteinuria lebih dari $2 \mathrm{mg} / 24$ jam atau > +2 pada dipstik. [2]

\section{TEORI TENTANG PATOFISIOLOGIS OBESITAS TERHADAP PREEKLAMPSIA}


Pada seseorang baik dengan kehamilan maupun tidak, terjadi disfungsi endotel yang dipicu oleh adanya obesitas, dimana hal ini akan menyebabkan kerusakan dari endotel dan semakin mempresipitasi terjadinya preeklampsia. Obesitas dapat meningkatkan resiko terjadinya preeklampsia dengan beberapa mekanisme. [2]

Penyebab preeklampsia pada obesitas lainnya adalah adanya melekul fibronectin (FN) yang berlebih pada obesitas, yang diteliti oleh Fibronectin adalah glikoprotein yang terdapat pada matriks ekstraselular, yang dihasilkan oleh sel epitel serta sel-sel endotel. Hasil dari penelitian tersebut adalah terdapat peningkatan kadar FN pada wanita hamil dengan obesitas, jika dibandingkan dengan wanita hamil yang memiliki berat badan normal. Pada trimester pertama tidak terdapat perubahan yang signifikan pada kadar FN terhadap wanita hamil dengan obesitas maupun tidak. Namun pada trimester kedua dan ketiga, terjadi kenaikan yang signifikan pada kelompok obesitas. [2]

Pada umumnya orang dengan obesitas memiliki pola makan dengan rendah serat serta tinggi kalori dan lemak. Rendahnya serat mengakibatkan sedikitnya konsumsi buah dan sayur dan penurunan antioksidan yang merupakan salah satu penyebab meningkatnya risiko preeklamsia [2]

Faktor gaya hidup juga mempengaruhi terjadinya obesitas. Gaya hidup, termasuk di dalamnya diet dan aktivitas fisik berhubungan dengan terjadinya obesitas dan penyakit kardiovaskular. Resiko terjadinya preeklamsia pada wanita obesitas juga berhubungan dengan gaya hidup. [2]

\section{HASIL PEMBAHASAN}

Preeklampsia merupakan suatu keadaan yang sering terjadi pada kehamilan dan dapat membahayakan kondisi ibu dan janin. Banyak faktor yang telah diketahui mempengaruhi terjadinya preeklampsia salah satunya adalah obesitas pada ibu hamil. Dengan adanya kenaikan berat badan sebesar $5-7 \mathrm{~kg} / \mathrm{m}^{2}$ akan memiliki peluang terjadinya preeklampsia sebesar 2 kali lipat.

Jadi dalam pembahasan yang penulis angkat tentang hubungan obesitas dengan kejadian preeklampsia pada ibu hamil, dapat disimpulkan menurut hasil pembahasan bahwa terdapat hubungan antara obesitas dengan kejadian 
preeklampsia dimana wanita hamil dengan obesitas memiliki resiko 2 kali lipat peluang untuk tertena preeklampsia.

Sehingga perlu perhatian bagi ibu hamil untuk untuk rutin melakukan kunjungan ANC, mencari informasi dari pelayanan kesehatan agar dapat meminimalisir kejadian yang berakibat buruk terhadap penyakit dan komplikasi yang diderita pada saat kehamilan, serta memperhatikan pola makan agar tetap terjaga berat badan selama masa kehamilan. 


\section{DAFTAR PUSTAKA}

1. Nur, Fahira A. 2017. Faktor Resiko Kejadian Preeklamsia Pada Ibu Hamil Di RSU Anutapura Kota Palu. Palu: Jurnal Kesehatan Tadulako http://jurnal.untad.ac.id/jurnal/index.php/HealthyTadulako/article/view/87

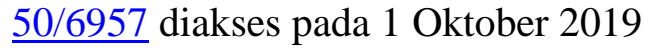

2. Wafiyatunisa, Zahra. 2016. Hubungan Obesitas Dengan Terjadinya Preeklampsia. Lampung: Juke Kedokteran Unila http://juke.kedokteran.unila.ac.id/index.php/majority/article/download/907 /815 dakses pada 4 Oktober 2019 